\title{
Desorption isotherms and isosteric heat of araticum (Annona crassiflora Mart.) seeds
}

\author{
Weder N. Ferreira Junior ${ }^{1}$, Osvaldo Resende ${ }^{1}$, Kelly A. de Sousa ${ }^{1}$, Melícia I. A. Gavazza ${ }^{1}$, \\ Juliana de F. Sales ${ }^{1} \&$ Daniel E. C. de Oliveira ${ }^{2}$ \\ ${ }^{1}$ Instituto Federal de Educação, Ciência e Tecnologia Goiano. Rio Verde, GO, Brasil. E-mail: wedernunesift,@gmail.com (Corresponding author) - \\ ORCID: 0000-0002-2931-9352; osvresende@gmail.com - ORCID: 0000-0001-5089-7846; kellyapsousa@yahoo.com.br - ORCID: 0000-0001-8360-8035; \\ melgavazza@hotmail.com - ORCID: 0000-0003-4493-4641; juliana.sales@ifgoiano.edu.br - ORCID: 0000-0002-6113-2707 \\ ${ }^{2}$ Instituto Federal de Educação, Ciência e Tecnologia Goiano. Iporá, GO, Brasil. E-mail: oliveira.d.e.c@gmail.com - ORCID: 0000-0002- 3824-994X
}

\begin{abstract}
The objective of this study was to determine the desorption isotherms and isosteric heat of Annona crassiflora Mart. seeds, using Akaike information criterion (AIC) and Schwarz's Bayesian information criterion (BIC) to assist in the choice of the nonlinear regression model. The desorption isotherms were determined by indirect static method and water activity was obtained using the instrument HygroPalm; the product was put in the device in B.O.D. chamber set at 10, 20, 30 and $40{ }^{\circ} \mathrm{C}$. Several nonlinear regression models were fitted to the experimental data by the Gauss-Newton method. The desorption isotherms of Annona crassiflora Mart. seeds can be represented by the models of Chung-Pfost, Copace, Modified GAB, Modified Henderson, Modified Oswin, Sabbah and Sigma Copace. However, the Sigma Copace model showed better fit to the experimental data, with lower AIC and BIC values, being chosen to represent the desorption isotherms of Annona crassiflora Mart seeds. Isosteric heat increased with decreasing moisture content, requiring a greater amount of energy to remove water from seeds, with values ranging from 2541.64 to $2481.56 \mathrm{~kJ} \mathrm{~kg}^{-1}$, for the moisture content range from 5.69 to $14.93 \%$ on a dry basis.
\end{abstract}

Key words: hygroscopicity, AIC, BIC, Sigma Copace

\section{Isotermas de dessorção e calor isostérico de sementes de araticum (Annona crassiflora Mart.)}

\begin{abstract}
RESUMO: Objetivou-se, com este estudo, determinar as isotermas de dessorção e o calor isostérico das sementes de Annona crassiflora Mart., utilizando os critérios de informação de Akaike (AIC) e informação bayesiano de Schwarz (BIC) para auxiliar na escolha do modelo de regressão não linear. As isotermas de dessorção foram determinadas pelo método estático indireto e a atividade de água foi obtida por meio do equipamento HygroPalm; o produto foi acondicionado no equipamento em B.O.D. regulada a 10, 20, 30 e $40{ }^{\circ} \mathrm{C}$. Os dados experimentais foram ajustados a diversos modelos de regressão não linear, pelo método Gauss-Newton. As isotermas de dessorção de sementes de Annona crassiflora Mart. podem ser representadas pelos modelos de Chung-Pfost, Copace, GAB Modificado, Henderson Modificado, Oswin Modificado, Sabbah e Sigma Copace. Contudo, o modelo Sigma Copace apresentou melhor ajuste aos dados experimentais, com memores valores de AIC e BIC, sendo escolhido para representar as isotermas de dessorção das sementes de Annona crassiflora Mart. O calor isostérico aumentou com a diminuição do teor de água, sendo necessária maior quantidade de energia para retirar a água das sementes, com valores variando de 2541,64 a 2481,56 kJ kg-1, para a faixa do teor de água de 5,69 a 14,93\% base seca.
\end{abstract}

Palavras-chave: higroscopicidade, AIC, BIC, Sigma Copace 


\section{INTRODUCTION}

Annona crassiflora Mart is a species native to the Cerrado, found in areas of 'dirty' grassland (grass and shrubs in shallow soil), whose fruits have a high commercial value, due to their several culinary uses. The popular names of these fruits are araticum, cabeça de negro and marolo. Besides the culinary use, crushed seeds are used in the treatment against ectoparasites in folk medicine (Maroni et al., 2006; Bernardes et al., 2007). Araticum seeds are orthodox, with grayish brown color, measuring from 1 to $2 \mathrm{~cm}$.

During storage, araticum seeds are characterized by being able to perform gas exchange of water vapor, a process known as hygroscopicity (Corrêa et al., 2005). Due to this phenomenon, it is necessary to conduct studies on the post-harvest processing of these seeds due to the importance of storage in maintaining physiological quality for the perpetuation of the species, enabling its commercial use in the food industry. Study on the hygroscopicity of plant products can be performed by fitting nonlinear regression models to experimental data, under different conditions of air temperature and relative humidity.

The nonlinear regression model can be chosen based on indices resulting from the fitting process, such as the coefficient of determination $\left(\mathrm{R}^{2}\right)$, mean relative error $(\mathrm{P})$, mean estimated error (SE) and Chi-square test $\left(\chi^{2}\right)$, which are traditionally used (Almeida et al., 2013; Ullmann et al., 2016). However, it can be noted the need for using a criterion that defines the best model among those which generate satisfactory results from the fitting.

In this context, Akaike information criterion (AIC) and Schwarz's Bayesian information criterion (BIC) can be used to choose the best model with best representation of the phenomenon, and these criteria have already been used by Ferreira Junior et al. (2018) and Gomes et al. (2018) in the mathematical simulation of hygroscopicity and drying processes, respectively.

Thus, the objective of this study is to determine the desorption isotherms and the isosteric heat of Annona crassiflora Mart. seeds, using Akaike information criterion (AIC) and Schwarz's Bayesian information criterion (BIC) to assist in the choice of the best mathematical model.

\section{Material And Methods}

The experiment was carried out at the Plant Products Postharvest Laboratory of the Instituto Federal de Educação,
Ciência e Tecnologia Goiano - IF Goiano, located in the municipality of Rio Verde, GO, Brazil. Annona crassiflora Mart seeds with initial moisture content of $16 \%$ on a dry basis (d.b.) were used for the study. The fruits were harvested manually in the rural region of the municipality of Itapuranga, GO, Brazil ( $15^{\circ} 42^{\prime} 72^{\prime \prime} \mathrm{S}$; $50^{\circ} 11^{\prime} 28^{\prime \prime} \mathrm{W}$ and altitude of $498 \mathrm{~m}$ ).

Subsequently, the seeds were cleaned in running water at the laboratory, their surface water was removed with paper towels, and the seeds were placed in a polyethylene plastic bag at $5{ }^{\circ} \mathrm{C}$ in B.O.D. chamber (Marconi, MA-415) until the tests were conducted.

To obtain the various moisture contents, the seeds were subjected to drying in an oven (Marconi, MA-035) with forced air ventilation at $40{ }^{\circ} \mathrm{C}$ and drying air relative humidity of $22.4 \%$, through the gravimetric method, knowing the initial moisture content of the seeds, until reaching the moisture contents of 15 to $6 \pm 0.50 \%$ d.b. Subsequently, the moisture contents were checked with $6.50 \mathrm{~g}$ samples in an oven (Nova Ética, 400-3ND) at $105 \pm 3{ }^{\circ} \mathrm{C}$, for $24 \mathrm{~h}$ (Brasil, 2009).

The desorption isotherms of Annona crassiflora Mart. seeds were determined using the static-indirect method, and their water activity $\left(\mathrm{a}_{\mathrm{w}}\right)$ was determined using the instrument HygroPalm model AW1 (Rotronic). The seeds were placed in triplicate for each moisture content, with approximately $6 \mathrm{~g}$ per sample and then put in a B.O.D. chamber (Marconi, MA-415) regulated at $10,20,30$ and $40{ }^{\circ} \mathrm{C}$. After simultaneous stabilization of temperature and water activity, these variables were read in the instrument and the final moisture content was determined for each sample, following the methodology of Brasil (2009).

Nonlinear regression models frequently used to represent the hygroscopicity of plant products (Silva et al., 2015; Barbosa et al., 2016; Ferreira Junior et al., 2018) were fitted to the experimental data, according to Eqs. 1 to 9, presented in Table 1.

The nonlinear regression models were fitted using the Gauss-Newton method, assessing the significance of their coefficients by the t test. In order to verify the degree of fit of each model, the magnitude of the coefficient of determination $\left(\mathrm{R}^{2}\right)$, mean estimated error $(\mathrm{SE})$, mean relative error $(\mathrm{P})$ and Chi-square test $\left(\chi^{2}\right)$ were evaluated at $\mathrm{p} \leq 0.01$.

For the mean relative error, value below $10 \%$ was considered as one of the criteria for selecting the models, according to Mohapatra \& Rao (2005). The mean estimated error (SE) and

Table 1. Nonlinear regression models used to estimate the hygroscopicity of Annona crassiflora Mart seeds

\begin{tabular}{lll}
\multicolumn{1}{c}{ Model } & \multicolumn{1}{c}{$\begin{array}{c}\text { Model } \\
\text { designation }\end{array}$} \\
$X e^{*}=\left[-1 /\left(c T^{d}\right)\right] \ln \left[\ln \left(a_{w}\right) /\left(-a T^{b}\right)\right]$ & Chen Clayton \\
$X e^{*}=a-b \ln \left[-(T+c) \ln \left(a_{w}\right)\right]$ & Chung-Pfost & $(1)$ \\
$X e^{*}=\exp \left[a-(b T)+\left(c a_{w}\right)\right]$ & Copace & $(2)$ \\
$X e^{*}=\left(a b a_{w}\right)\left[(c / T) /\left(1-b a_{w}+(c / T) b a_{w}\right)\left(1-b a_{w}\right)\right]$ & Modified $G A B$ \\
$X e^{*}=\left[\ln \left(1-a_{w}\right) /-a(T+b)\right]^{1 / c}$ & Modified Henderson \\
$X e^{*}=(a+b T)\left[a_{w} /\left(1-a_{w}\right)\right]^{1 / c}$ & Modified Oswin \\
$X e^{*}=\left[\left(a a_{w}{ }^{b}\right)+\left(c a_{w}{ }^{d}\right)\right]$ & Peleg \\
$X e^{*}=a\left(a_{w}{ }^{b / T^{c}}\right)$ & Sabbah & $(4)$ \\
$X e^{*}=\exp \left\{a-(b T)+\left[c \exp \left(a_{w}\right)\right]\right\}$ & Sigma Copace \\
\hline
\end{tabular}

$\mathrm{Xe}^{*}$ - equilibrium moisture content, \% d.b.; $\mathrm{a}_{\mathrm{w}}$ - water activity, decimal; $\mathrm{T}$ - Temperature, ${ }^{\circ} \mathrm{C} ; \mathrm{a}, \mathrm{b}, \mathrm{c}, \mathrm{d}$ - Coefficients that depend on the product 
mean relative error $(\mathrm{P})$, as well as the Chi-square test $\left(\chi^{2}\right)$ for each of the models, were calculated according to Eqs. 10, 11 and 12 , respectively:

$$
\begin{aligned}
& \mathrm{SE}=\sqrt{\frac{\sum(\mathrm{Y}-\hat{\mathrm{Y}})^{2}}{\mathrm{DF}}} \\
& \mathrm{P}=\frac{100}{\mathrm{n}} \sum \frac{|\mathrm{Y}-\hat{\mathrm{Y}}|}{\mathrm{Y}} \\
& \chi^{2}=\sum \frac{(\mathrm{Y}-\hat{\mathrm{Y}})^{2}}{\mathrm{DF}}
\end{aligned}
$$

where:

Y - experimental value;

$\hat{Y} \quad$ - value estimated by the model;

n - number of experimental observations; and,

DF - residual degrees of freedom (number of observations minus number of parameters of the model).

AIC makes it possible to use the principle of parsimony in the choice of the best model, that is, according to this criterion, the most parameterized model is not always better (Burnham \& Anderson, 2004). AIC is used to compare non-nested models or when three or more models are being compared. Lower AIC values reflect better fit (Akaike, 1974). AIC can be defined by Eq. 13.

$$
\mathrm{AIC}=-2 \log \text { like }+2 \mathrm{p}
$$

where:

$\mathrm{p}$ - number of parameters; and,

loglike - value of the logarithm of the likelihood function considering the estimates of the parameters.

BIC also considers the degree of parameterization of the model and, likewise, the lower the BIC value (Schwarz, 1978), the better the fit of the model. BIC is an asymptotic criterion, whose adequacy is strongly related to the magnitude of the sample size. In relation to the penalty applied to the number of parameters, this is stricter than AIC for small samples. BIC can be defined by Eq. 14 .

$$
\mathrm{BIC}=-2 \log \operatorname{like}+\mathrm{p} \ln (\mathrm{n})
$$

where:

n - number of observations used to fit the curve.

Isosteric heat, which refers to the amount of energy needed to remove water from the product, was estimated. To obtain the isosteric heat, the water activity values of Annona crassiflora Mart. seeds were obtained from the model used in the fitting of the isotherms. The net isosteric heat (or differential enthalpy), for each moisture content, was calculated according to Clausius-Clapeyron Eq. 15 (Iglesias \& Chirife, 1976):

$$
\frac{\partial \operatorname{In}\left(\mathrm{a}_{\mathrm{w}}\right)}{\partial \mathrm{T}}=\frac{\Delta \mathrm{h}_{\mathrm{st}}}{\mathrm{RT}_{\mathrm{a}}^{2}}
$$

where:

$\mathrm{a}_{\mathrm{w}} \quad$ - water activity (decimal)

$\mathrm{T}_{\mathrm{a}}$ - absolute temperature, $\mathrm{K}$;

$\Delta \mathrm{h}_{\text {st }}$ - differential enthalpy, $\mathrm{kJ} \mathrm{kg}^{-1}$; and,

$\mathrm{R}$ - universal gas constant for water vapor $(0.4619 \mathrm{~kJ}$ $\left.\mathrm{kg}^{-1} \mathrm{~K}^{-1}\right)$.

By integrating Eq. 15 and assuming that the net isosteric heat of sorption is independent of temperature, the net isosteric heat, for each moisture content, was obtained according to Eq. 16:

$$
\operatorname{Ln}\left(\mathrm{a}_{\mathrm{w}}\right)=-\left(\frac{\Delta \mathrm{h}_{\mathrm{st}}}{\mathrm{R}}\right) \frac{1}{\mathrm{~T}_{\mathrm{a}}}+\mathrm{C}
$$

where:

C - coefficient of the model.

The integral isosteric heat was obtained by adding the values of net isosteric heat of sorption and latent heat of vaporization of free water (L), as shown in Eq. 17, according to Corrêa et al. (1998):

$$
\mathrm{Q}_{\mathrm{st}}=\Delta \mathrm{h}_{\mathrm{st}}+\mathrm{L}=\mathrm{a} \exp (-\mathrm{bXe})+\mathrm{c}
$$

where:

$\mathrm{Q}_{\mathrm{st}} \quad$ - Integral isosteric heat of sorption, $\mathrm{kJ} \mathrm{kg}^{-1}$;

$\mathrm{Xe} \quad$ - equilibrium moisture content, \% d.b.;

$\Delta \mathrm{h}_{\text {st }}$ - differential enthalpy, $\mathrm{kJ} \mathrm{kg}^{-1}$;

$\mathrm{a}, \mathrm{b}$ and c - coefficient of the model; and,

$\mathrm{L} \quad$ - latent heat of vaporization of free water, $\mathrm{kJ} \mathrm{kg}^{-1}$.

The latent heat of vaporization of free water $(\mathrm{L})$, in $\mathrm{kJ} \mathrm{kg}^{-1}$, necessary for calculating $\mathrm{Q}_{\mathrm{st}}$, was obtained using the average temperature $(\mathrm{T})$ in the study range, in ${ }^{\circ} \mathrm{C}$, by means of Eq. 18 :

$$
\mathrm{L}=2502.2-2.39 \mathrm{~T}
$$

\section{Results AND Discussion}

Table 2 shows the experimental data of water activity obtained for the different moisture contents and temperatures from the static-indirect method.

Table 2 shows that the experimental moisture contents ranged from 5.69 to $14.93 \%$ d.b. The difference from that estimated in the methodology (15 to $6 \%$ d.b.) is due to the desorption process that occurs during the reading time in the instrument, which can last $4 \mathrm{~h}$ per sample depending on the condition. In addition, it is observed that water activity increases with increasing moisture content and temperature.

Table 3 shows the coefficients of the models and the magnitudes of mean relative error $(\mathrm{P})$, mean estimated error (SE), Chi-square test $\left(\chi^{2}\right), \mathrm{AIC}, \mathrm{BIC}$ and coefficient of determination $\left(\mathrm{R}^{2}\right)$. 
Table 2. Values of water activity - $\mathrm{a}_{\mathrm{w}}$ (decimal) of Annona crassiflora Mart. seeds, as a function of moisture content (\% d.b.) and temperature $\left({ }^{\circ} \mathrm{C}\right)$

\begin{tabular}{|c|c|c|c|c|c|c|c|}
\hline \multicolumn{2}{|c|}{$10 \pm 0.3^{\circ} \mathrm{C}$} & \multicolumn{2}{|c|}{$20 \pm 0.3^{\circ} \mathrm{C}$} & \multicolumn{2}{|c|}{$30 \pm 0.3^{\circ} \mathrm{C}$} & \multicolumn{2}{|c|}{$40 \pm 0.3^{\circ} \mathrm{C}$} \\
\hline Moisture content & $a_{w}$ & Moisture content & $\mathbf{a}_{w}$ & Moisture content & $a_{w}$ & Moisture content & $a_{w}$ \\
\hline 6.52 & 0.545 & 5.69 & 0.536 & 5.94 & 0.548 & 6.02 & 0.563 \\
\hline 7.74 & 0.641 & 7.66 & 0.656 & 7.55 & 0.678 & 7.78 & 0.671 \\
\hline 10.08 & 0.761 & 9.81 & 0.756 & 9.31 & 0.777 & 9.48 & 0.793 \\
\hline 12.81 & 0.858 & 12.75 & 0.854 & 12.86 & 0.855 & 12.57 & 0.851 \\
\hline 14.12 & 0.869 & 14.80 & 0.906 & 14.63 & 0.916 & 14.93 & 0.920 \\
\hline
\end{tabular}

Table 3. Coefficients of the models fitted to the water activity levels Annona crassiflora Mart. seeds, with their fitting indices

\begin{tabular}{|c|c|c|c|c|c|c|c|}
\hline Models & Coefficients & SE & $\mathbf{P}(\%)$ & $\overline{x^{2}}$ & AIC & BIC & $\mathbf{R}^{21}$ \\
\hline Chen Clayton & $\begin{array}{l}a=2.30156^{*} \\
b=-0.04038^{n s} \\
c=0.17761^{\star *} \\
d=0.04722^{n s}\end{array}$ & 0.410 & 2.93 & 0.1736 & 26.45 & 31.46 & 0.9866 \\
\hline Chung-Pfost & $\begin{array}{l}\mathrm{a}=28.0103^{\star \star} \\
\mathrm{b}=4.85010^{\star *} \\
\mathrm{c}=133.1326^{\star \star}\end{array}$ & 0.415 & 3.20 & 0.1726 & 26.12 & 30.10 & 0.9854 \\
\hline Copace & $\begin{array}{l}\mathrm{a}=0.38549^{\star *} \\
\mathrm{~b}=0.00245^{\star} \\
\mathrm{c}=2.59319^{\star \star}\end{array}$ & 0.459 & 3.61 & 0.2107 & 30.23 & 34.22 & 0.9822 \\
\hline Modified GAB & $\begin{array}{l}a=3.89380^{\star *} \\
b=0.82570^{* *} \\
c=171.1116^{\star \star}\end{array}$ & 0.397 & 3.02 & 0.1578 & 24.34 & 28.33 & 0.9866 \\
\hline Modified Henderson & $\begin{array}{l}\mathrm{a}=0.00033^{* *} \\
\mathrm{~b}=252.2288^{* *} \\
\mathrm{c}=1.20590^{* *}\end{array}$ & 0.631 & 4.58 & 0.398 & 24.82 & 28.80 & 0.9863 \\
\hline Modified Oswin & $\begin{array}{l}a=6.36642^{\star \star} \\
b=-0.00270^{\star \star} \\
c=2.41773^{\star \star}\end{array}$ & 0.524 & 3.83 & 0.2743 & 35.46 & 39.44 & 0.9768 \\
\hline Peleg & $\begin{array}{l}\mathrm{a}=15.5141^{\mathrm{ns}} \\
\mathrm{b}=3.69831^{\mathrm{ns}} \\
\mathrm{c}=3.76204^{\mathrm{ns}} \\
\mathrm{d}=-0.2641^{\mathrm{ns}}\end{array}$ & 0.690 & 4.82 & 0.4761 & 35.72 & 40.70 & 0.9787 \\
\hline Sabbah & $\begin{array}{l}a=17.1832^{\star \star} \\
b=1.3223^{\star \star} \\
c=-0.1182^{\star}\end{array}$ & 0.622 & 5.20 & 0.3868 & 41.02 & 45.01 & 0.9663 \\
\hline Sigma Copace & $\begin{array}{l}\mathrm{a}=-0.25815^{\star \star} \\
\mathrm{b}=0.00264^{\star \star} \\
\mathrm{c}=1.21598^{\star *}\end{array}$ & 0.386 & 2.89 & 0.1491 & 23.28 & 27.26 & 0.9874 \\
\hline
\end{tabular}

ns, ${ }^{*},{ }^{* *}$ - Not significant, significant at $\mathrm{p} \leq 0.05$ and $\mathrm{p} \leq 0.01$, respectively, by test $\mathrm{t} ;{ }^{1}-\mathrm{R}^{2}$ is on a unit scale, not decimal; SE- Mean estimated error; $\mathrm{P}$ - Mean relative error; $\chi^{2}-$ Chisquare test; AIC - Akaike information criterion; BIC - Schwarz's Bayesian information criterion; $\mathrm{R}^{2}$ - Coefficient of determination

The coefficients of determination $\left(\mathrm{R}^{2}\right)$ of the fitted models ranged from 0.9663 to 0.9874 . The models of Chen Clayton, Chung Pfost, Copace, Modified GAB, Modified Henderson and Sigma Copace showed $\mathrm{R}^{2}$ higher than 0.9822 , and the Sigma Copace model had the highest value (0.9874).

For both the mean relative error $(\mathrm{P})$ and the mean estimated error (SE), the values obtained were low (Table 3). It is observed that the Sigma Copace model had the lowest value of mean estimated error (0.386) and the Peleg model had the highest value (0.690). According to Draper \& Smith (1998), the capacity of a model to represent a physical process is inversely proportional to the value of mean estimated error. All values of mean relative error are below $10 \%$, indicating adequate representation of the studied phenomenon (Mohapatra \& Rao, 2005); the Sigma Copace model had the lowest value (2.89\%) for P.

Regarding the Chi-square test $\left(\chi^{2}\right)$, all fitted models were significant. For the comparison of the magnitude of $\chi^{2}$ test values (Table 3), the Chen Clayton, Chung-Pfost, Modified GAB and Sigma Copace models showed the lowest values compared to the others.

The coefficients of the Chung-Pfost, Copace, Modified GAB, Modified Henderson, Modified Oswin, Sabbah and
Sigma Copace models were significant at $\mathrm{p} \leq 0.01$ and 0.05 by the $t$ test. For the Chen Clayton model the coefficients $b$ and $d$ were not significant. None of the coefficients of the Peleg model was significant by the $t$ test. Therefore, the Chen Clayton and Peleg models cannot be used to estimate the experimental data, as they may generate errors of estimate.

All models tested to represent the hygroscopicity of Annona crassiflora Mart. seeds, exception Chen Clayton and Peleg models, had satisfactory values of the fitting indices: coefficients of determination $\left(\mathrm{R}^{2}\right)$ close to 1 , low values of mean relative error $(\mathrm{P})$ and mean estimated error $(\mathrm{SE})$, as well as low values of Chi-square $\left(\chi^{2}\right)$, in addition to significant values of the coefficients of the models by the $\mathrm{t}$-test, indicating that they are adequate for representing the studied phenomenon.

Therefore, to define the model to be used to graphically represent the desorption isotherms, among the models considered satisfactory, the AIC and BIC criteria were used as auxiliary indices (Table 3). The Sigma Copace model had the lowest values of AIC and BIC, when compared to the others, and according to the literature (Akaike, 1974; Schwarz, 1978), lower values of these indices define the best model. 
The AIC and BIC indices were used in the mathematical modeling of the isotherms of Hymenae stigonocarpa Mart. seeds (Ferreira Junior et al., 2018) to help in choosing the best model that expresses the hygroscopicity of the species.

The Sigma Copace model was then used to represent the desorption isotherms of Annona crassiflora Mart. seeds (Figure 1).

For isotherms of Crambe abyssinica fruits, Costa et al. (2015) found that the Sigma Copace model fitted best to the phenomenon of hygroscopicity, as observed in other studies (Chaves et al., 2015; Barbosa et al., 2016; Corrêa et al., 2016a; Ullmann et al., 2016).

It can be observed in Figure 1 that water activity increased as the temperature increased and, for a constant water activity, the values of moisture content decreased with increasing temperature, following the same trend of most plant products: seeds of Anacardium othonianum Rizz. (Caetano et al., 2012); Physalis peruviana L. (Vega-Gálvez et al., 2014); diaspores of Caryocar brasiliense, CAMB. (Sousa et al., 2016).

The desorption isotherms obtained for Annona crassiflora Mart. seeds by the Sigma Copace model did not show a sigmoidal shape in the studied range of water activity, as observed for most plant products, such as Capsicum chinense L seeds. (Silva et al., 2015) and Beta vulgaris seeds (Corrêa et al., 2016b).

The curves of the isotherms, in the water activity range from 0.53 to 0.92 (decimal), were classified as type III, according to their shapes (IUPAC, 1985), as verified for some products, such as Vigna angularis Willd (Almeida et al., 2013), fruits of Crambe abyssinica (Costa et al., 2015) and achene of Anacardium humile St. Hil. (Barbosa et al., 2016).

The development of pathogenic microorganisms in plant products begins with water activity around 0.7 (Oliveira et al., 2005); therefore, it can be observed that the moisture contents recommended for safe storage of Annona crassiflora Mart. seeds, ensuring their physiological quality, are at most 8.76, $8.50,8.27$ and $8.04 \%$ d.b., for the respective temperatures of

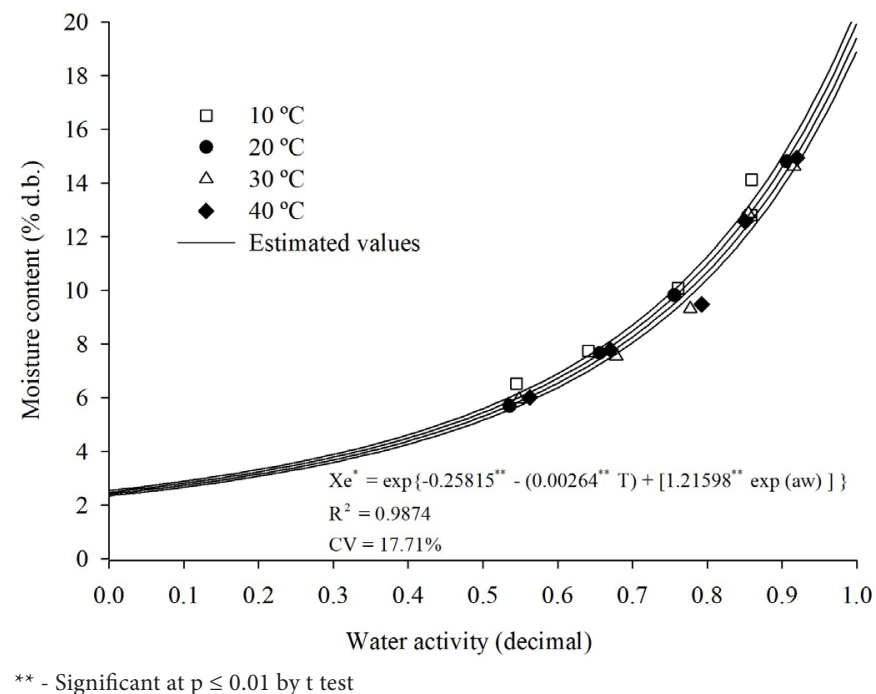

Figure 1. Experimental values of water activity and desorption isotherms estimated by Sigma Copace model for Annona crassiflora Mart. seeds under different conditions of temperature and water activity
$10,20,30$ and $40{ }^{\circ} \mathrm{C}$, and these values were estimated by the Sigma Copace model.

For the values of the integral isosteric heat of desorption $\left(\mathrm{Q}_{\mathrm{st}}\right)$, as a function of the moisture content (\% d.b.) (Figure 2), with the reduction in moisture content, there was an increase in the energy necessary to remove water from the product, represented by the values of the integral isosteric heat of desorption $\left(\mathrm{Q}_{\mathrm{st}}\right)$, as observed for several plant products, such as fruits of Capsicum annuum L. (Alves et al., 2015) and Opuntia ficus-indica (Hassini et al., 2015).

From the analysis of Figure 2, as mentioned by Teixeira et al. (2015), it was possible to verify that, as the moisture content of the product decreases, more energy must be provided for water removal. Furtado et al. (2014), working with Dipteryx alata Vog. almond, obtained isosteric heat from 443.33 to $631.91 \mathrm{~kJ} \mathrm{~kg}^{-1}$ for the moisture content range from 15.00 to $3.50 \%$ d.b., respectively. This behavior of low moisture content requires a greater amount of energy, corroborating the results of the present study.

The values of integral isosteric heat in the desorption of Annona crassiflora Mart. seeds in the moisture content range from 5.69 to 14.93 (\% d.b.) varied from 2541.64 to $2481.56 \mathrm{~kJ} \mathrm{~kg}^{-1}$. According to Chaves et al. (2015), for Jatropha curcas L. seeds, at temperatures of $10,20,30$ and $40{ }^{\circ} \mathrm{C}$ and equilibrium moisture content ranging from 5.6 to 13.4 (\% d.b.), the integral isosteric heat varied from 3035.61 to $2631.89 \mathrm{~kJ} \mathrm{~kg}^{-1}$. Thus, Jatropha curcas seeds require a greater amount of energy, being less susceptible to water losses during the drying process when compared to Annona crassiflora Mart. seeds.

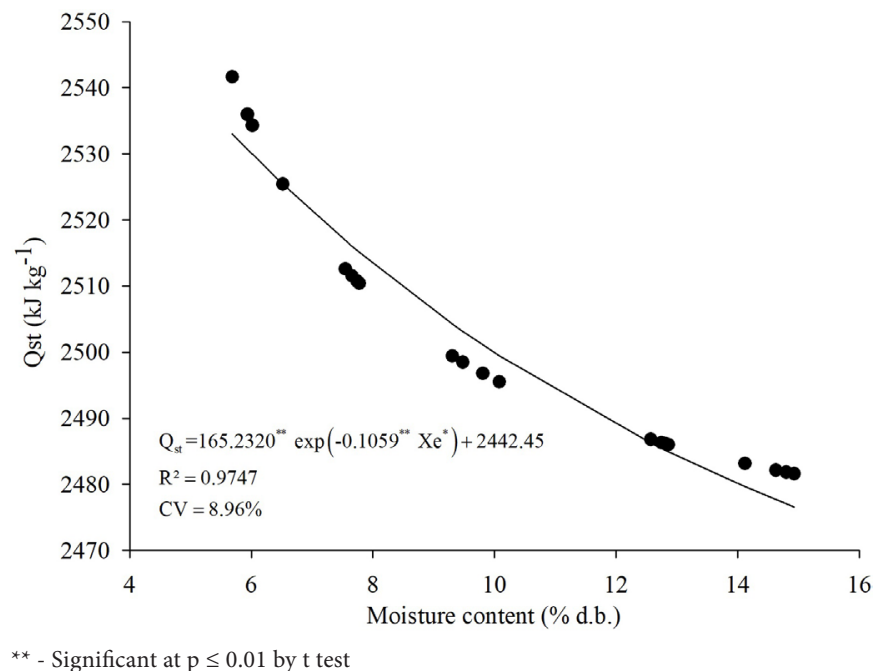

Figure 2. Experimental and estimated values of the integral isosteric heat of desorption $\left(\mathrm{Q}_{\mathrm{st}}\right)$ defined according to the moisture content of Annona crassiflora Mart. seeds

\section{Conclusions}

1. The desorption isotherms of Annona crassiflora Mart. seeds can be represented by the Chung-Pfost, Copace, Modified GAB, Modified Henderson, Modified Oswin, Sabbah and Sigma Copace models.

2. The Sigma Copace model was chosen to predict the desorption isotherms of Annona crassiflora Mart. seeds, based on Akaike information criterion (AIC) and Schwarz's Bayesian information criterion (BIC). 
3. The isosteric heat increased with the reduction in moisture content, requiring a greater amount of energy to remove water from the seeds, with values ranging from 2541.64 to $2481.56 \mathrm{~kJ} \mathrm{~kg}^{-1}$, for the moisture content range from 5.69 to $14.93 \%$ dry basis.

\section{ACKNOWLedgments}

To Instituto Federal de Educação, Ciência e Tecnologia Goiano, Coordenação de Aperfeiçoamento de Pessoal de Nível Superior, Fundação de Amparo à Pesquisa do Estado de Goiás and Conselho Nacional de Desenvolvimento Científico e Tecnológico, for the indispensable financial support to conduct the study.

\section{Literature Cited}

Akaike, H. A new look at the statistical model identification. IEEE Transaction on Automatic Control, v.19, p.716-723, 1974. http:// dx.doi.org/10.1109/TAC.1974.1100705

Almeida, D. P.; Resende, O.; Costa, L. M.; Mendes, U. C. Higroscopicidade das sementes de feijão adzuki. Científica, v.41, p.130-137, 2013. http://dx.doi.org/10.15361/19845529.2013v41n2p130-137

Alves, T. P.; Fóz, H. D.; Nicolet, J. F. Isotermas de dessorção de pimentão verde e energia envolvida no processo. Brazilian Journal of Food Technology, v.18, p.137-145, 2015. http://dx.doi. org/10.1590/1981-6723.6114

Barbosa, K. F.; Sales, J. de F.; Resende, O.; Oliveira, D. E. C. de; Zuchi, J.; Sousa, K. A. de. Desorption isotherms and isosteric heat of 'cajuzinho-do-cerrado' achenes. Revista Brasileira de Engenharia Agrícola e Ambiental, v.20, p.481-486, 2016. http://dx.doi. org/10.1590/1807-1929/agriambi.v20n5p481-486

Bernardes, T. G.; Estrêla, C. T.; Naves, R. V.; Rezende, C. F. A.; Mesquita, M. A. M.; Pires, L. L. Efeito do armazenamento e de fitohormônios na qualidade fisiológica de sementes de araticum (Annona crassiflora Mart.). Pesquisa Agropecuária Tropical, v.37, p.163-168, 2007.

Brasil. Ministério da Agricultura, Pecuária e Abastecimento. Regras para análise de sementes. Brasília: MAPA, 2009. 398p.

Burnham, K. P.; Anderson, D. R. Multimodel inference: Understanding AIC and BIC in model selection. Sociological Methods \& Research, v.33, p.261-304, 2004. https://doi.org/10.1177/0049124104268644

Caetano, G. de S.; Sousa, K. A. de; Resende, O.; Sales, J. de F.; Costa, L. M. Higroscopicidade de sementes de caju-de-árvore-do-cerrado. Pesquisa Agropecuária Tropical, v.42, p.437-445, 2012. http:// dx.doi.org/10.1590/S1983-40632012000400012

Chaves, T. H.; Resende, O.; Oliveira, D. E. C. de; Smaniotto, T. A. S.; Sousa, K. A. de. Isotermas e calor isostérico das sementes de pinhão-manso. Engenharia na Agricultura, v.23, p.9-18, 2015. http://dx.doi.org/10.13083/reveng.v23i1.591

Corrêa, P. C.; Christ, D.; Martins, J. H.; Mantovani, B. H. M. Curvas de dessorção e calor latente de vaporização para as sementes de milho pipoca (Zea mays). Revista Brasileira de Engenharia Agrícola e Ambiental, v.2, p.75-79, 1998. http://dx.doi.org/10.1590/18071929/agriambi.v2n1p75-79

Corrêa, P. C.; Oliveira, G. H. H. de; Oliveira, A. P. L. R. de; Goneli, A. L. D.; Botelho, F. M. Isotermas de dessorção de sementes de beterraba. Engenharia na Agricultura, v.24, p.15-21, 2016b. http:// dx.doi.org/10.13083/1414-3984/reveng.v24n1p15-21
Corrêa, P. C.; Oliveira, G. H. H. de; Oliveira, A. P. L. R. de; VargasElías, G. A.; Baptestini, F. M. Particle size and roasting on water sorption in conilon coffee during storage. Coffee Science, v.11, p.221-233, 2016a.

Corrêa, P. C.; Resende, O.; Ribeiro, D. M. Isotermas de sorção das espigas de milho: obtenção e Modelagem. Revista Brasileira de Milho e Sorgo, v.4, p.126-134, 2005. https://doi.org/10.18512/19806477/rbms.v4n1p126-134

Costa, L. M.; Resende, O.; Oliveira, D. E. C. de. Determinação das isotermas de equilíbrio higroscópico de frutos de crambe pelo método dinâmico. Bioscience Journal, v.31, p.382-391, 2015. https://doi.org/10.14393/BJ-v31n2a2015-22337

Draper, N. R.; Smith, H. Applied regression analysis. 3.ed. New York: John Wiley \& Sons, 1998. 712p. https://doi. org/10.1002/9781118625590

Ferreira Junior, W. N.; Resende, O.; Oliveira, D. E. C. de; Costa, L. M. Isotherms and isosteric heat desorption of Hymenaea stigonocarpa Mart. seeds. Journal of Agricultural Science, v.10, p.504-512, 2018. https://doi.org/10.5539/jas.v10n10p504

Furtado, G. de F.; Silva, F. S. da; Porto, A. G.; Santos, P. dos. Dessorção e calor isostérico de amêndoas de baru. Revista Brasileira de Tecnologia Agroindustrial, v.8, p.1416-1427, 2014. https://doi. org/10.3895/S1981-36862014000200010

Gomes, F. P.; Resende, O.; Sousa, E. P. de; Oliveira, D. E. C. de; Araújo Neto, F. R. de. Drying kinetics of crushed mass of 'jambu': Effective diffusivity and activation energy. Revista Brasileira de Engenharia Agrícola e Ambiental, v.22, p.499-505, 2018. http:// dx.doi.org/10.1590/1807-1929/agriambi.v22n7p499-505

Hassini, L.; Bettaieba, E.; Desmorieuxb, H.; Torresc, S. S.; Touild, A. Desorption isotherms and thermodynamic properties of prickly pear seeds. Industrial Crops and Products, v.67, p.457-465, 2015. http://dx.doi.org/10.1016/j.indcrop.2015.01.078

Iglesias, H.; Chirife, J. Isosteric heats of water vapour sorption on dehydrated foods. Part II: Hysteresis and heat of sorption comparison with BET theory. Lebensmittel Wissenschaft and Technologie, v.9, p.123-127, 1976.

IUPAC - International Union of Pure and Applied Chemistry. Reporting physisorption data for gas/solid systems with special reference to the determination of surface area and porosity (Recommendations 1984). Pure \& Applied Chemistry, v.57, p.603619, 1985. https://doi.org/10.1351/pac198557040603

Maroni, B. C.; Stasi, L. C.; Machado, S. R. Plantas medicinais do cerrado de Botucatu - Guia Ilustrado. São Paulo: Editora UNESP, 2006. 200p.

Mohapatra, D.; Rao, P. S. A thin layer drying model of parboiled wheat. Journal of Food Engineering, v.66, p.513-518, 2005. https://doi. org/10.3895/S1981-36862014000200010

Oliveira, M. M. de; Campos, A. R. N.; Gomes, J. P.; Silva, F. L. H. da. Isotermas de sorção do resíduo agroindustrial de casca do abacaxi (Ananas comosus L. Mer). Revista Brasileira de Engenharia Agrícola e Ambiental, v.9, p.565-569, 2005. http:// dx.doi.org/10.1590/S1415-43662005000400020

Schwarz, G. Estimating the dimension of a model. Annals of Statistics, v.6, p.461-464, 1978. http://dx.doi.org/10.1214/aos/1176344136

Silva, H. W. da; Costa, L. M.; Resende, O.; Oliveira, D. E. C. de; Soares, R. S.; Vale, L. S. R. Higroscopicidade das sementes de pimenta (Capsicum chinense L.). Revista Brasileira de Engenharia Agrícola e Ambiental, v.19, p.780-784,2015. http://dx.doi. org/10.1590/1807-1929/agriambi.v19n8p780-784 
Sousa, K. A. de; Resende, O.; Carvalho, B. de S. Determination of desorption isotherms, latent heat and isosteric heat of pequi diaspore. Revista Brasileira de Engenharia Agrícola e Ambiental, v.20, p.493-498, 2016. http://dx.doi.org/10.1590/1807-1929/agriambi.v20n5p493-498

Teixeira, L. P.; Andrade, E. T. de; Espíndola, J. Z.; Pereira, R. G. Determinação do equilíbrio higroscópico e do calor isostérico do bagaço de cana-de-açúcar. Engenharia Agrícola, v.35, p.555-566, 2015. http://dx.doi.org/10.1590/1809-4430-Eng.Agric.v35n3p555-566/2015
Ullmann, R.; Resende, O.; Oliveira, D. E. C. de; Costa, L. M.; Chaves, T. $\mathrm{H}$. Higroscopicidade das sementes de sorgo-sacarino. Engenharia Agrícola, v.36, p.515-524, 2016. http://dx.doi.org/10.1590/18094430-Eng.Agric.v36n3p515-524/2016

Vega-Gálvez, A.; López, J.; Ah-Hen, K.; Torres, M. J.; Lemus-Mondaca, R. Thermodynamic properties of cape gooseberry. Food Technology and Biotechnology, v.52, p.83-92, 2014. 